\title{
READERS
Insight
}

Journal of Management Info (JMI)

ISSN:2313-3376

www.readersinsight.net/jmi

MA

\section{Impact of social media brand communication on brand knowledge: Mediating role of brand image $\&$ brand awareness application of CBBE model theory of keller}

\author{
Anam Bhatti $^{1 *}$, Mariam $^{2}$, SumbalArif ${ }^{3}$, SohailYounas $^{4}$ \\ 1,2,3,4 Department of Management Sciences, University of Sargodha, Gujranwala, Pakistan \\ ${ }^{4}$ Department of Management Sciences, University of Punjab, Gujranwala campus, Pakistan \\ * Corresponding author: gujranwalaanam091@gmail.com
}

\begin{abstract}
We live in $21^{\text {st }}$ century, where the use of social media is growing day by day. Individuals prefer social media for personal and professional use. Corporations are also communicating with their customers through social media which increases awareness about the product of a specific brand that ultimately develops brand knowledge. The basic objective of this study is to explore the relationship between social media brand communication and brand knowledge by considering brand image and brand awareness as mediators. This study is quantitative in nature hence for the purpose of data collection questionnaire method was adopted. 200 questionnaires were distributed among the students of business department. Data was tested through SPSS (Statistical Packages for the Social Science) as well as AMOS (Analysis Movement of Structure) Software. Findings of this research show there is a positive and significant relationship between social media brand communication and brand knowledge. Moreover, brand image and brand awareness extensively mediate the relationship between social media brand communication and brand knowledge.
\end{abstract}

ARTICLE INFORMATION

Received: August March 2017

Revised: September 2017

Accepted: November 2017

DOI:

http://dx.doi.org//10.31580/jmi.v15i1.72

\section{Introduction}

Due to the web 2.0 telecommunications, organizations are adopting social media in order to endorse as well as to communicate information relevant to their brands. With the passage of time people are moving towards the social media and according to estimation, people are increasing year by year at the percentage of 34 across the globe which is engaged with the social media. They have adirect opportunity in the direction of social media. Brands are using social media as a medium for the purpose of delivering their messages to their audience. Because of the social media, the customary promotional techniques have been changed. Online users have considered that brand communication through the social media is an influential tool which is effectively managed by the marketer. As a result of changing trends the one directional communication is now converted in different directions, now it's the time of two ways communication. Customers can properly feedback to the organizations after getting theexperience of their products(Dessart, Veloutsou, \& Morgan-Thomas, 2015). It relates to the CBBE model theory of Keller because by delivering the message to a mass audience at the same time its image will be developed, awareness will be created and at the end, brand equity will be increased. The major advantage of social media is that huge audience can be targeted at the same time and proper feedback can be obtained as soon as possible. Moreover, social media has changed the existing advertising approach. It has expanded the association between the customers plus brands. Brand image can be developed due to these connections. Firms can create a separate brand identity due to its uniqueness. It can be developed with the passage of time by using various modes like advertising appeals, or different types of promotional campaigns. A well-known brand image is very effective to develop an extraordinary environment of the brand, protect the brand from its challengers, and upgrade the brand's achievements in the market along with maintaining along-lasting relationship(Anselmsson, Vestman Bondesson, \& Johansson, 2014). Additionally brand is obvious and ethical in its visualization. In short, it is an inclusive evaluation of brand. Furthermore when a brand satisfies the consumers then it can attain a good repute in the market. So the companies have to identify the customer's trends as well as market situations with the intention of fulfilling their needs and create a separate image, provide the quality products, along with separate identification apart from its competitors. In this way people will attract towards the brand and awareness will be enhanced. Brand awareness is gaining importance day by day in the context of advertising. Brand awareness is the capability that the customers recognized the brand efficiently. Brand instills in their evoked set. So they prefer a specific brand and always prefer it due to its distinctiveness during the period of purchasing a product or availing a service. The product can easily and effectually promote with the help of brand awareness because brands can easily advertise its products but for the gaining profit, it is necessary to create differentiation for the reason of getting acompetitive edge. Which enhance the brand equity as well because it connected with the CBBE model of Keller. This theory is supported by these variables. Furthermore, if customers are well aware then they can save their time by promptly taking the decisions. Similarly, customers can prefer those brands about which they are familiar; they considered that brand as trustworthy, have confidence, feel satisfaction because their lifestyles are purely linked with those brands. It is treated as 
animportant ingredient of branding(Vidal, 2016). Brand awareness generally considered as animportant objective of the organizations because without it organizations can't survive. Brand awareness directly influences the brand knowledge for the reason that due to a good brand image customer's attention will be captured by the brand. They pay proper concentration on the way to brand for getting awareness. Then a curiosity developed in their minds and they gained more information about it.Furthermore, Brand knowledge does not create the delight only, although it generates psychological along with behavioral distinction in the associations in order to make certain that sellers have theaffirmative brand knowledge and does not feel hesitation for purchasing a branded product. Experimental reactions of the consumers hit the brand knowledge(Watkins, Aitken, Robertson, Thyne, \& Williams, 2016). While the advertiser enhances the promotional efficiency than the basic reason behind it increasing the brand knowledge which directs to customer based brand equity. In the memory of the users brand knowledge is important for them because when they think about a specific brand what comes in their minds first, it strongly affects their perceptions. Brand knowledge is a wide term which covers brand awareness and brand image(Tufekci, 2012). Due to increment in this customer's loyalty improved. This basically determines the affection with a brand. Lastly put together the powerful and fascinating a brand is the first and foremost goal because the whole success depends upon it.

\section{Literature review}

\section{Social media brand communication}

Social media involves avariety of applications as well as websites which allow the end-users to generate and to share any content with the other users. It also includes the contribution of users in social networking(Dessart et al., 2015). Social media basically computer based instruments which permit the people and organizations to produce or interchange such message, pictures, videos, thoughts with others. Due to the innovation and advancement in the technology the standard of living of the corporations is revolutionizing day by day. Companies have instigated to realize the significance of the World Wide Web. Due to the supremacy of web 2.0 telecommunications, the online coverage by the users has been increased from which the mainly essential is social media(Eagleman, 2013). Social media is a medium which involves consumers and organization associated with each other. Companies disseminate the information and influence the customers through the social networks in order to check the responses from the target audience. Along with conventional resources of communication social media have been ascertained the world widely(Golob et al., 2013). The reason of this effective reputation is due to the virally spreading the brand's information over the world by the means of web based technology. Furthermore, Social media allows the people to provide feedback to the brands after using a product or availing a service. Additionally, social media is considered as acrucial foundation for the purpose of communicating a message of the brand over the audience. It is treated as more confidential authority for providing information than the conventional mediums of marketing adopted by the brands(Hollebeek, Glynn, \& Brodie, 2014). So many organizations think that social media will be beneficial for communicating with the peoples and provide information to them. Social media brand communication is a wide term, in which two further dimensions are included firm created social media brand communication and customer's generated social media brand communication. The difference between these exists because firm created communication is under the supervision of the administration whereas the user generated brand communication is treated as selfregulating by the firms(J. Huang, Baptista, \& Galliers, 2013). Furthermore, firms generated social media brand communication generally relates to the electronic words of mouth. It can be supposed as a combination of customary promotion as well as customer's words of mouth. Social media brand communication can be enhanced through online messaging or through viral marketing. Which support to CBBE model of Keller because due to the social media brand image will be created, brand knowledge will be developed afterward brand awareness will be increased and organizations will earn aprofit. Therefore online sources of communication are treated as aprominent tool for distributing information among the users(Hudson, Roth, Madden, \& Hudson, 2015). Lastly, user generated communication has been gaining fame due to the online brand communications. Because it becomes a source of publicity about the brand as well as involve the creative efforts by the organizations.

\section{Brand image}

The brand consists of any name, sign, symbol or assortment of all these in order to recognize the product or service as well as differentiating it from its competitors. Brand image is the consciousness about the brand personality in the minds of theconsumer. It generally represents what the brand put up with and entails a guarantee by theorganization to its customers. It also elaborates how customers perceived the brand(Anselmsson et al., 2014).Basically, thebrand image consists of aset of ideas in the perception of the consumer regarding a certain brand. Moreover, brand image is the valuation of a product in the customer's memory because it has genuine and purely practical links with the psyche of customers. Brand image is significant because it provides assistance to the end user to determine whether a specified brand is suitable for him/her or not.Furthermore, for the purpose of reminding particulars about a product brand image can be used as an observant(Chen, Yeh, \& Huan, 2014). In the current era of thebusiness brand image of a corporate is considered as assets of the business because people mostly attract towards a well-known brand having a strong image in their sensations. Ultimately brand image represents basic standards as well thewhole reflection of the organization. The personality of the brand is generally revealed by its image so it is extremely important for a business. The brand image also establishes the sales of the product because an appealing brand image magnetizes the customers towards buying a product for the reason that it makes the decision process easier(Fatema, Azad, \& Masum, 2015). A well-known brand image is that which enhanced the sales of product and in due course improved its profit. Similarly, brand image is arelationship which is associated with the customers in their perceptions(Grohs \& Reisinger, 2014). Additionally, it is thesum of all physical as well as nonphysical qualities. It consists of all domestic plus exterior uniqueness. Furthermore, it can be anything or everything which strongly identifies that in which way the brands are judged by the consumers in their minds(Johnson \& Zinkhan, 2015). Lastly, brand image is treated as best, profitable speculation tool adopted by the brands. CBBE model of Keller is associated with thebrand image. Brand image entirely supports this theory because brand image is generally connected with the memory of the customers and these memories strong influence the evaluation process when a customer evaluate a brand on the basis of its distinctiveness plus favorability(Namkung \& Jang, 2013).

\section{Brand awareness}

A brand can be clarified as any sign, name, expression, or composition of all these, that explains as well as classifies a commodity, furthermore, it develops a specialty which discriminates the product from its competitors(Balmford, Borland, \& Yong, 2016). Similarly brand is an assurance to stabilized association among end viewers. Moreover, it is a chain of rational plus expressive credentials. On the other hand, awareness means domination which is developed by the brand in the minds of their consumers(Barreda, Bilgihan, Nusair, \& Okumus, 2015). As the essential element brand awareness directly hits the intellection of the audience as well as leads to brand loyalty. Generating brand awareness is generally the first and foremost step in order to develop a brand(Foroudi, Dinnie, Kitchen, Melewar, \& Foroudi, 2016).It doesn't involve containing know how about the brand or having anobservation about the brand, it involves the relationship with the brand name, logo, sign, symbol, plus complete knowledge of brand in the perceptions of the end users. It is also an important instrument in the development of 
intercommunication because beyond brand awareness possibility does not exist in order to achieve the consequences of corresponding. It sustains the CBBE model of Keller and purely inter-relate with this theory(R. Huang \& Sarigöllü, 2014). Due to this understanding will be developing. After that, according to Keller, these feelings will directly hit to the brand equity theory. Additionally, brand awareness also includes the differential expressions like color, packaging, shape, and many other features of a specific brand. In addition to the perspective of business to consumer brand awareness can be explained as: it has the ability to evoke the brand, to discriminate the brand from its rivalries, together with influence the decisions of the customers. It strongly relates to the consumer'sdecision-making process because it has the capacity to enhance the purchasing capability of the target audience(Lambert-Pandraud, Laurent, Mullet, \& Yoon, 2016). Brand awareness consists of acknowledgment, familiarity, supremacy, and reminds of the brand in the knowledge of individuals. Likewise, brand awareness also elaborates in this sense that due to this buyer become recognizable about the unique attributes on the other hand regarding the prestige of an appropriate brand which deals with various products and services(Lu, Chang, \& Chang, 2014). Besides this it can be determined in the head of two sections, intensity along with extent, first of all, intensity means power of the brand that signifies how purchasers remember an exacting brand similarly chances of obtaining plus availing services of a brand can be occurred due to the extent of brand awareness particularly when a brand surface deeply in the minds of customers(Sasmita \& Mohd Suki, 2015). Additionally, brand awareness is considered as amost significant factor for the purpose of enhancing the brand equity in the orbit of Business 2 Business.

\section{Brand knowledge}

In the current era due to the extraordinary cost, higher rivalry, along with minor demand in thecountless marketplace, organizations are putting their concentration toward enhanced the effectiveness of their promotion expenditures. By the reason of it is necessary to properly understand the brand equity in order to increase market efficiency(Brennan, Professor Sue Halliday, France, Merrilees, \& Miller, 2015). While the vendors develop the market knowledge concerning the brand in the perception of the consumers then it generally direct towards the customer based brand equity which purely supports the theory of Keller CBBE model. Brand knowledge is strongly influenced in the mind of the end users due to the temporary market strategies(Giri \& Sharma, 2014). Brand knowledge is amost sophisticated tool because after having knowledge about a particular brand users become competent to rememorize the information regarding the brand efficiently and quickly. Brand knowledge effectively hits the perceptions of the customers for the reason that it enforces the peoples for the purpose of selecting a brand according to their knowledge(Hemsley-Brown, Melewar, Nguyen, \& Wilson, 2016). Brand knowledge leads to responsiveness, elements, familiarity, feeling, reflection as well as repute of the brand. These above-mentioned directions basically involved developing connections with the consumers in the context of business to business marketing. The basic motive in the wake of such application is to remind the end users about the dominating brands by using their brand knowledge and their desires for the period of procuring(Kang, Tang, \& Fiore, 2014). Brand knowledge helps the organizations to create an encouraging brand position in the minds of the purchaser. It also judged as acompetitive tool for the reason that when the companies provide knowledge about their brand to the distributors then companies assured that all the information is properly understandable by the sellers, it becomes a competitive edge for the companies. It strongly related with the relationship between the brand and customer(Koll \& von Wallpach, 2014). Brand knowledge concept is purely relevant with the CBBE model of Keller. He explained that the brand knowledge is a success factor because the strength of the organization largely depends upon what the consumers have experienced the brand as well as rememorize the brand quickly(Tatlow-Golden, Hennessy, Dean, \& Hollywood, 2014).
Brand knowledge generally enhances the associations with customers according to this theory. Lastly, consumers can recall their memories on the basis of brand knowledge for the reason it puts a deep effect on their minds(ur Rehman \& Kausar, 2016).

\section{The relationship between social media brand communication and brand knowledge}

Companies used social media for accessing plus collecting customer to customer communication for the reason that it is low cost and unconventional tool. Social media brand communication is at a standstill believed asthe latest process between marketers(Killian \& McManus, 2015). Due to this brand knowledge, increased so significant relationship exists between them. When the companies will deliver their messages then ultimately it positively affects brand knowledge(Hudson et al., 2015).

H1:There is apositive relationship between social media brand communication and brand knowledge.

\section{The mediating role of brand image \\ Social media brand communication and brand image}

Social media communication directly hits the brand image because when companies will publicize its quality products and differentiate it from their rivals then a brand image will be developed(Dessart et al., 2015).

H2: There is apositive and significant relationship among social media brand communication and brand image.

\section{Brand image and brand knowledge}

Brand image and brand knowledge are strongly interrelated with each other because when a brand image of a specific brand is good then theconsumer will gain more knowledge about this brand(Sasmita \& Mohd Suki, 2015). Ultimately brand knowledge will be enhanced.

H3:There is asignificant relationship between brand image and brand knowledge.

\section{The mediating role of brand awareness \\ Social media brand communication \& brand awareness}

There is apositive relationship between these variables for the reason that when a message will virally spread towards the target audience then a sense of awareness will be developed(Kohli, Suri, \& Kapoor, 2015).

H4: There is positive and significant association between Social media brand communication and brand awareness

\section{Brand awareness and brand knowledge}

Awareness generally generates a sense of liking or disliking. When a customer is well aware of a brand then he will be conscious of getting more knowledge about it. Consequently, it shows that a direct relationship occurs in between(Sasmita \& Mohd Suki, 2015).

H5:There is positive relationship between brand awareness and brand knowledge 


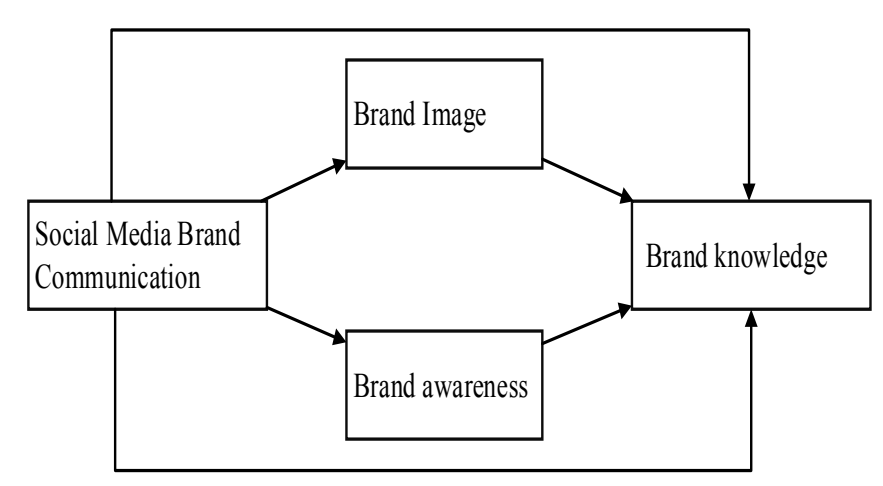

Fig. 1. Theoretical Framework

Methodology

This basic rationale of this study is to investigate the correlation among social media brand communication, brand image, brand awareness as well as brand knowledge.

\section{Research philosophy}

The research philosophy of this research is positivism philosophy, for the reason that the results are generally obvious and experimental. There are minimum biases in the data and ultimate results are found and in this research, theobserver has no delicate estimation and interprets results and deliberate on figures. As a philosophy positivism adheres to the view that only "factual" knowledge enhanced in the course of inspection including dimensions, is reliable. According to the principles of positivism, it depends on quantifiable observations that lead themselves to statistical analysis. It has been noted that "as a philosophy, positivism is in accordance with the empiricist view that knowledge stems from human experience. Moreover, in positivism studies, the researcher is self-determining from the study and there are no prerequisites for human interests within the study. Additionally, positivism relates to the viewpoint that researcher needs to concentrate on facts, whereas phenomenology deliberates on the meaning and has provision for human interest.

\section{Research approach}

In this study, the research approach is deductive in nature. Because in this research hypothesis is developed which are purely based on existing theory, different strategies are designed in order to test this hypothesis, which will be accepted or rejected after examining the outcome of the results. Furthermore,in this study, we examine the outcome of social media brand communication on brand knowledge throughout the mediating role of brand image \& brand awareness. The deductive approach can be clarified by the means of assumptions, which can be developed from the suggestions of the theory. In other words, adeductive approach is concerned with deducing conclusions from premises or propositions. "Deduction instigates with an anticipated outline that is tested aligned with observations. In other words, when a deductive approach is being pursued in the research the author originates a set of hypotheses that need to be experienced.

\section{Research method/design}

The research method is quantitative. Quantitative methods highlight objective measurements and the numerical, statistical, analysis of data collected through opinion polls, questionnaires, in addition to surveys, or by manipulating pre-existing statistical data using computational techniques. Quantitative research focuses on assembling numerical data and simplifying it across groups of people or to clarify an exacting experience. So the study encloses "quantitative research method" because in thestudy the data is collected by aprimary source.Quantitative research deals in numbers, logic, and an objective position. Quantitative research focuses on numeric and unchanging data and detailed. The data is usually collected using controlled research tools. The results are based on larger sample sizes that are representative of the population. Similarly, the research study can usually be simulated or repeated, given its high consistency. Our data are in the form of statistics and figures, often arranged in tables, charts, figures, or other non-textual forms. Lastly, the project can be used to simplify concept more broadly, forecast future results, or examine fundamental relationships.

\section{Sampling technique}

The sampling technique in this research is "non-probability convenience sampling technique" because of convenience sampling, as the name implies is a specific type of non-probability sampling method that consistsof data collection from population members who are conveniently available to participate in thestudy. Convenience sampling is a type of sampling wherever the initial accessible primary data source will be used for the research without extra conditions. In other words, this sampling method includes receiving contributors where you can discover them and typically wherever is convenient. In convenience sampling, no inclusion criteria identified prior to selection of subjects. All subjects are invited to participate.

\section{Sample size}

As for as sample size is concerned, Hair et al, expressed a thumb rule to facilitate sample size through which sample size can be achieved by multiplying the total objects in a questionnaire by 10 .

\section{Data collection method}

The data collection method is survey method by questionnaire design. A questionnaire is a research instrument depending on a series of questions for the purpose of collecting information from respondents. Questionnaires are also sharply restricted by the fact that respondents must be able to read the questions and respond to them accordingly.

\section{Measures}

All the scales which are used in this study have been adopted by different researchers in the previous research. These scales are reliable because the alpha Cronbach value is less than 0.07.

\section{Social media brand communication}

For the purpose of collecting data 10 items scale of Aaker Cizonkota \& Ronkaenin is adopted.

\section{Brand image}

The scale of prashtant raj baniya is used for the purpose of measuring brand image.

\section{Brand awareness}

20 items scale of Aaker Cizonkota \& Ronkaenin is approved for measuring brand awareness.

\section{Brand knowledge}

The scale of Blumberg et al., 2008; Churchill, 1995; Saunders et al., 2012) is adopted.

\section{Data analysis}

\section{Demographics analysis}

Demographicssection illustrates the information about respondents' gender, age, and education level, nature of employment and length of service. We distributed 200 questionnaires to the responses of respondents out of which 153 valid questionnaires received. 79 filled by males and 74 filled by female respondents whose percentage is $51.6 \%$ and $48.8 \%$ respectively. Most respondents were between the age group of $46-55$ whose percentage is $0 \%$.According to this $28.1 \%$ and $71.9 \%$ be of the age group of $26-45$ and age group of up to 25 respectively.Furthermore, respondents were $36.6 \%, 53.6 \%$, and $9.8 \%$ belonged to Bachelor's, Master's, Ph.D.'scorrespondingly.

Table 1: Mean and Information of the Constructs 


\begin{tabular}{llllllll}
\hline Construct & Mean & SD & $\mathbf{\alpha}$ & $\mathbf{1}$ & $\mathbf{2}$ & $\mathbf{3}$ & $\mathbf{4}$ \\
\hline SMBC & 3.67 & .425 & .77 & -- & & & \\
BI & 3.82 & .370 & .76 & $.326^{* *}$ & -- & & \\
BA & 3.74 & .528 & .71 & $.534^{* *}$ & $.251^{* *}$ & -- & \\
BK & 3.89 & .650 & .79 & $.269^{* *}$ & $.271^{* *}$ & $.247^{* *}$ & -- \\
\hline
\end{tabular}

SMBC=Social media brand communication, BI=Brand Image, BA=Brand Awareness, $\mathrm{BK}=$ Brand knowledge

\section{Results}

The above-mentioned table is representing the descriptive statistics, reliability and Pearson correlation among all understudies variables. The highest correlation existed between Brand awareness and social media brand communication which is valued at 0.534 . It is reflecting that social media brand communication and brand awareness are positively related to each other with a moderate standard deviation. All other variables named as brand image and brand knowledge are also associated with each other. The mean values are showing the trend of responses that most of them are laid towards agreeableness. Results indicate that alpha values for all variables are under satisfactory range to verify data reliability.

Table 2: Fit Indices for CFA Model

\begin{tabular}{lllllll}
\multicolumn{1}{l}{ Index of fit } & CMIN/df & $\mathbf{P}$ & GFI & AGFI & CFI & RMSEA \\
\hline Value & 3.04 & .07 & .937 & .826 & .947 & .053 \\
\hline
\end{tabular}

Table2 of Fit Indices Model illustrates the Goodness of Fit Chi Square and other values to determine that whether the chosen model has been an appropriate fit for reliability and validity check or not. Goodness of Fit Index (GFI) should be greater than 0.95, Adjusted Goodness of Fit should be greater than 0.8, CFI should be $>0.95$, Root Mean Square Error of Approximation should be $<0.5$. Thus, the results value of our measurement model being GFI $=0.937$, AGFI $=0.826, \mathrm{CFI}=0.947$, RMSEA $=0.053$ being in thenormal range of acceptance proves that our model is fit to check the reliability and validity of scale being used providing a green signal to proceed.

Table 3: Indices for CFA Model Fit

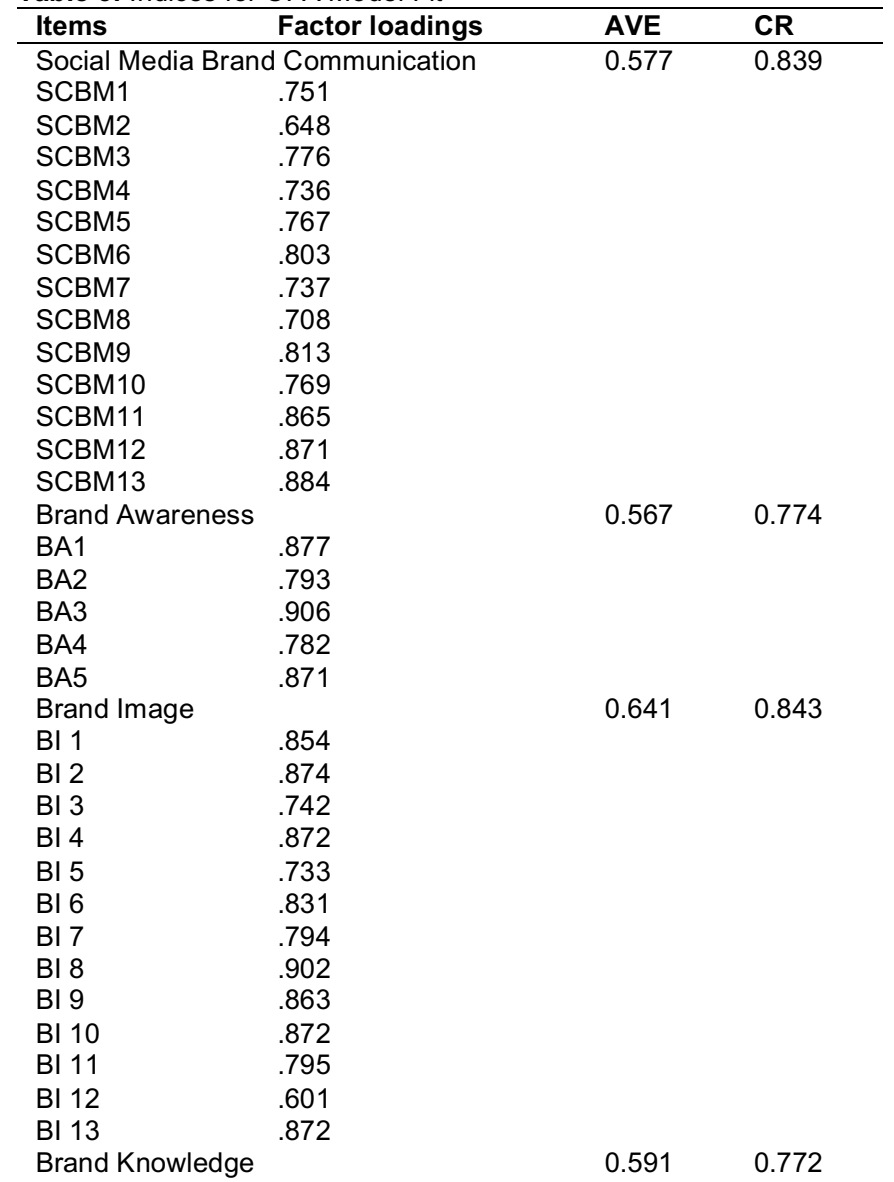

\begin{tabular}{ll} 
BK1 & .863 \\
BK2 & .872 \\
BK3 & .916 \\
BK4 & .873 \\
BK5 & .723 \\
BK6 & .840 \\
\hline
\end{tabular}

To run Confirmatory Factor Analysis the measurement model has been adopted. Table3 shows the CFA Model which indicates the convergent reliability and discriminant validity of data, this model, and its fit indices have been demonstrated. Fornell and Larcker(1981),investigates that there are three steps to check the reliability which involve the factor loading generates thevalue of CFI Model being more than 0.7, the AVE values should be more than 0.5 and the Composite Reliability (CR) value should be more than 0.5 . Hence, the results are shown in Table 3 explain that the most of the values of factor loading are greater than 0.7 and significant at 0.001 . Whereas the CR and AVE values are all more than 0.8 and 0.5.According to results our scale is convergent reliable and proves the discriminant validity, which elaborates that the variables are inconsistent with each other.

Table 4: Model Fit and Index of Fit of the Model

\begin{tabular}{lllllll}
\hline Index of fit & CMIN/Df & P & GFI & AGFI & CFI & RMR \\
\hline Value & 2.99 & .05 & .95 & .876 & .951 & .05 \\
\hline
\end{tabular}

Table 4 represents the fit indices of SEM. Which determine the fitness between the recommended and the existing variance.The first value anticipated by the index of fit beindchisuare (DF) $=2.99$ specifies the fitness of model being used. Therefore, the GFI shows the variance in the model which is 0.95 which is quite fair, AGFI value being 0.876 shows quite a good fit, the CFI value intimates the difference between two models and 0.951 value is good, the RMR value indicating the difference between estimated variance and covariance from observed value being small as 0.05 is good, CFI comparative fit index value 0.951 is considered good. Thus, the result proves that the data is authentic according to the model.

Table 5: Structural Model Regression Weights

\begin{tabular}{|c|c|c|c|c|c|c|}
\hline & & & Estimate & S.E. & C.R & $\mathbf{P}$ \\
\hline $\mathrm{Bk}$ & $\leftarrow$ & SMBC & .442 & .094 & .056 & .015 \\
\hline $\mathrm{BI}$ & $\leftarrow$ & SMBC & .481 & .088 & 1.25 & .034 \\
\hline $\mathrm{BI}$ & $\leftarrow$ & BK & .376 & .075 & 2.82 & .025 \\
\hline $\mathrm{BA}$ & $\leftarrow$ & SMBC & .398 & .078 & 1.51 & .018 \\
\hline BA & $\leftarrow$ & BK & 354 & 0.76 & 0.66 & .023 \\
\hline
\end{tabular}

For asignificance level of relationship, the above-mentioned table indicates the regression weights which are hypothesized in H1, H2, $\mathrm{H} 3, \mathrm{H} 4$ and $\mathrm{H} 5$. The results show that all variables have positive and significant and positive relationship, therefore, all hypothesis $(\mathrm{H} 1$, $\mathrm{H} 2, \mathrm{H} 3, \mathrm{H} 4$, and $\mathrm{H} 5)$ are supported because $(\mathrm{p}<0.05)$. Moreover, SEM analysis indicated the positive estimates and S.E in relation with independent variables to thedependent variable. So all the variables including social media brand communication, brand knowledge, brand image and brand awareness are correlated with each other.

\begin{tabular}{lll}
\multicolumn{2}{l}{ Table 5: SEM Path Analysis } & \\
\hline Independent variable & Effects & Brand knowledge \\
\hline Social media brand & Direct Effect & $.442^{*}$ \\
communication & Indirect Effect & $.389^{*}$ \\
& Total Effect & $.498^{*}$ \\
& Direct Effect & $.481^{*}$ \\
& Indirect Effect & $.376^{*}$ \\
& Total Effect & $.549^{*}$ \\
\hline
\end{tabular}

Mediating variable: Brand Image, Brand Awareness

Path analysis of variables as well as their relationships is expressed in this table. To explain the directions of relationship all the values of direct and indirect effect has been provided. Greater value indirect effect shows the strong mediation effect of thebrand image between 
Social media brand communication, and brand knowledge. The value of total effect is also high which indicates that brand image and brand awareness are significant mediators among social media brand communication and brand knowledge.

\section{Discussion and conclusion}

The essential goal of this study is to investigate the relationship stuck between social media brand communication, brand image, brand awareness over and above brand knowledge. For this purpose we conduct this study and then hypothetically test it throughout questionnaire survey method from the students of business department belongs to different universities. This study verifies that relationship between social media brand communication and brand knowledge is significant. The existing literature surrounded by social media brand communication, brand image, brand awareness as well as brand knowledge is empirically tested through hypothesis. These hypotheses show that positive and significant relationship exists between all the variables which include social media brand communication, brand image, brand awareness and brand knowledge. Brand image and brand awareness considerably and positively mediate the relationship between social media brand communication and brand knowledge. This research supports to the previous literature. Furthermore, this study presents an important contribution to the contemporary part of theliterature on the social media brand communication, which purely supports to CBBE theory of Keller. The assessment of theimpact of social media brand communication on CBBE model reveals that firm-created social media brand communication strongly persuades the brand awareness, which ultimately enhances the worth of the firms. Similarly, social media provides a platform to the consumers to engage with a product or brand and convey their views to the marketers. In this way brand awareness takes place and ultimately brand knowledge enhanced. If the image of the brand is good then it creates a positive effect on the end users. Brand managers should prefer to the social media for the purpose of communication. In last we conclude that the findings of this study are positive which means that all five hypotheses are accepted. The first hypothesis reveals that there is apositive and significant relationship among social media brand communication and brand knowledge, which is accepted because when we communicate with the huge population then knowledge about the brand will be increased. The second hypothesis falls between social media brand communication and brand image, which is also recognized. Because when a good message is to be delivered to the audience then theimage of the brand builds up. The third hypothesis consists of abrand image and brand knowledge, which means brand image strongly expand a credible knowledge about the brand. Fourthly social media brand communication also improves the brand awareness. Lastly, the brand awareness produces brand knowledge in depth. So these hypotheses purely support to the previous studies.

\section{Practical implications}

The findings of this research would be applicable in thecase of business practices. It provides many ways to the marketers to introduce their product or brand by the mean of social media brand communication, and then brand awareness will be developed;ultimately a pool of brand knowledge will take place. So the practical implication of this study relates to the industries as well as the business sector in order to build a good brand name or identity. Therefore it is suitable for the marketers in order to grow their businesses.

\section{Limitations and future direction}

There are some limitations in this research that can provide instruction for the future research. First of all, a wide range of industries can be scrutinized in future. Sample size can be increased in future. Research method which is quantitative can also be changed; a qualitative study can be conducted. Additionally, we can generalize this research in different countries at international level. Variables can be changed or increased; their dimensions can be elaborate in depth. A longitudinal research can be developed as well as multiple channels can be adopted for the purpose of data collection.

\section{References}

Anselmsson, J., Vestman Bondesson, N., \& Johansson, U. (2014). Brand image and customers' willingness to pay a price premium for food brands. Journal of Product \& Brand Management, 23(2), 90-102.

Balmford, J., Borland, R., \& Yong, H. H. (2016). Impact of the introduction of standardised packaging on smokers' brand awareness and identification in Australia. Drug and alcohol review, 35(1), 102-109.

Barreda, A. A., Bilgihan, A., Nusair, K., \& Okumus, F. (2015). Generating brand awareness in online social networks. Computers in Human Behavior, 50, 600-609.

Brennan, R., Professor Sue Halliday, D., France, C., Merrilees, B., \& Miller, D. (2015). Customer brand co-creation: A conceptual model. Marketing Intelligence \& Planning, 33(6), 848-864.

Chen, H.-B., Yeh, S.-S., \& Huan, T.-C. (2014). Nostalgic emotion, experiential value, brand image, and consumption intentions of customers of nostalgic-themed restaurants. Journal of Business Research, 67(3), 354360 .

Dessart, L., Veloutsou, C., \& Morgan-Thomas, A. (2015). Consumer engagement in online brand communities: a social media perspective. Journal of Product \& Brand Management, 24(1), 28-42.

Eagleman, A. N. (2013). Acceptance, motivations, and usage of social media as a marketing communications tool amongst employees of sport national governing bodies. Sport Management Review, 16(4), 488-497.

Fatema, M., Azad, M. A. K., \& Masum, A. K. M. (2015). Impact of Brand Image and Brand Loyalty in Measuring Brand Equity of Islami Bank Bangladesh Ltd. Asian Business Review, 2(1), 42-46.

Foroudi, P., Dinnie, K., Kitchen, P. J., Melewar, T., \& Foroudi, M. M. (2016). IMC antecedents and the consequences of planned brand identity in higher education. European Journal of Marketing.

Giri, B., \& Sharma, S. (2014). Manufacturer's pricing strategy in a two-level supply chain with competing retailers and advertising cost dependent demand. Economic Modelling, 38, 102-111.

Golob, U., Elving, W. J., Ellerup Nielsen, A., Thomsen, C., Schultz, F., Podnar, K., \& Colleoni, E. (2013). CSR communication strategies for organizational legitimacy in social media. Corporate Communications: an international journal, 18(2), 228-248.

Grohs, R., \& Reisinger, H. (2014). Sponsorship effects on brand image: The role of exposure and activity involvement. Journal of Business Research, 67(5), 1018-1025.

Hemsley-Brown, J., Melewar, T., Nguyen, B., \& Wilson, E. J. (2016). Exploring brand identity, meaning, image, and reputation (BIMIR) in higher education: A special section: Elsevier.

Hollebeek, L. D., Glynn, M. S., \& Brodie, R. J. (2014). Consumer brand engagement in social media: Conceptualization, scale development and validation. Journal of Interactive Marketing, 28(2), 149-165.

Huang, J., Baptista, J., \& Galliers, R. D. (2013). Reconceptualizing rhetorical practices in organizations: The impact of social media on internal communications. Information \& Management, 50(2), 112-124.

Huang, R., \& Sarigöllü, E. (2014). How brand awareness relates to market outcome, brand equity, and the marketing mix Fashion Branding and Consumer Behaviors (pp. 113-132): Springer.

Hudson, S., Roth, M. S., Madden, T. J., \& Hudson, R. (2015). The effects of social media on emotions, brand relationship quality, and word of mouth: An empirical study of music festival attendees. Tourism Management, 47 , 68-76.

Johnson, M., \& Zinkhan, G. M. (2015). Defining and measuring company image. Paper presented at the Proceedings of the 1990 Academy of Marketing Science (AMS) Annual Conference.

Kang, J., Tang, L., \& Fiore, A. M. (2014). Enhancing consumer-brand relationships on restaurant Facebook fan pages: Maximizing consumer benefits and increasing active participation. International Journal of Hospitality Management, 36, 145-155.

Killian, G., \& McManus, K. (2015). A marketing communications approach for the digital era: Managerial guidelines for social media integration. Business horizons, 58(5), 539-549.

Kohli, C., Suri, R., \& Kapoor, A. (2015). Will social media kill branding? Business horizons, 58(1), 35-44.

Koll, O., \& von Wallpach, S. (2014). Intended brand associations: Do they really drive consumer response? Journal of Business Research, 67(7), 1501-1507. 
Lambert-Pandraud, R., Laurent, G., Mullet, E., \& Yoon, C. (2016). Impact of age on brand awareness sets: a turning point in consumers' early 60s. Marketing Letters, 1-14.

Lu, L.-C., Chang, W.-P., \& Chang, H.-H. (2014). Consumer attitudes toward blogger's sponsored recommendations and purchase intention: The effect of sponsorship type, product type, and brand awareness. Computers in Human Behavior, 34, 258-266.

Namkung, Y., \& Jang, S. S. (2013). Effects of restaurant green practices on brand equity formation: Do green practices really matter? International Journal of Hospitality Management, 33, 85-95.

Sasmita, J., \& Mohd Suki, N. (2015). Young consumers' insights on brand equity: Effects of brand association, brand loyalty, brand awareness, and brand image. International Journal of Retail \& Distribution Management, 43(3), 276-292.

Tatlow-Golden, M., Hennessy, E., Dean, M., \& Hollywood, L. (2014). Young children's food brand knowledge. Early development and associations with television viewing and parent's diet. Appetite, 80, 197-203.
Tufekci, Z., \& Wilson, C. (2012). (2012). Social media and the decision to participate in political protest: Observations from Tahrir Square. Journal of Communication, 16.

ur Rehman, M., \& Kausar, A. R. (2016). Managing Customer-Based Brand Equity (CBBE) Through Brand Knowledge Management Rediscovering the Essentiality of Marketing (pp. 587-598): Springer.

Vidal, L., Antúnez, L., Giménez, A., Varela, P., Deliza, R., \& Ares, G. (2016). Can consumer segmentation in projective mapping contribute to a better understanding of consumer perception. Food Quality and Preference, 6472.

Watkins, L., Aitken, R., Robertson, K., Thyne, M., \& Williams, J. (2016) Advertising's impact on pre-schoolers' brand knowledge and materialism. International Journal of Consumer Studies, 40(5), 583-591. 